\title{
Between roundhouse and villa: assessing perinatal and infant burials from Piddington, Northamptonshire
}

Article

Accepted Version

Hodson, C. M. ORCID: https://orcid.org/0000-0002-3408-2871 (2017) Between roundhouse and villa: assessing perinatal and infant burials from Piddington, Northamptonshire. Britannia, 48. pp. 195-219. ISSN 1753-5352 doi:

https://doi.org/10.1017/s0068113×17000137 Available at http://centaur.reading.ac.uk/98378/

It is advisable to refer to the publisher's version if you intend to cite from the work. See Guidance on citing.

Published version at: http://dx.doi.org/10.1017/s0068113x17000137

To link to this article DOI: http://dx.doi.org/10.1017/s0068113x17000137

Publisher: Cambridge University Press

All outputs in CentAUR are protected by Intellectual Property Rights law, including copyright law. Copyright and IPR is retained by the creators or other copyright holders. Terms and conditions for use of this material are defined in 
the End User Agreement.

www.reading.ac.uk/centaur

\section{CentAUR}

Central Archive at the University of Reading

Reading's research outputs online 


\section{Between Roundhouse and Villa: Assessing Perinatal and Infant Burials from Piddington, Northamptonshire.}

Claire M. Hodson

KEY WORDS: Infant: Burial: Piddington: Health: Growth: Stress

Abstract: The discovery of perinatal and infant individuals is common in the excavation of Iron Age and Romano-British domestic sites. In recent years, the discovery of many such burials has led to interpretations of infanticide and unceremonious disposal. Although this has been a widely considered phenomenon, much of the literature has focussed on the funerary context, and the biological age and sex estimates of these individuals, with little consideration of the palaeopathological evidence. This paper provides a detailed analysis of 17 perinates/infants from the Late Iron Age/Early Roman site of Piddington, Northamptonshire. It discusses the skeletal evidence for poor health and growth, and highlights the potential of these remains to reveal alternative insights into perinatal and infant death. Evidence of growth changes and pathological lesions were identified, suggesting that these individuals experienced chronic episodes of poor health that affected their skeletal development. The study explores the implications of these findings, within the context of Iron Age and Roman Britain. At Piddington, the death of these infants is not associated with the cultural practice of infanticide, but occurred due to poor health, highlighting the precarious nature of infant survival in the past.

Perinatal $^{1}$ and infant ${ }^{2}$ skeletal remains from archaeological sites have historically received minimal attention; sometimes discarded altogether ${ }^{3}$, many of those excavated are absent from excavation reports and published literature ${ }^{4}$. Today, interest in perinatal and infant studies from a range of disciplines is increasing, particularly within bioarchaeology, where much research has investigated factors related to childhood stress, social inclusion and care of children in the past ${ }^{5}$. Studies of perinatal and infant remains from Iron Age and Romano-British domestic sites have focused on the funerary and social contexts of

\footnotetext{
${ }^{1}$ The term perinate is used to refer to individuals between 36 and 44 weeks of gestational age. The term perinate means 'around birth' and thus these parameters allow for a 4 week (1 month) range either side of the standard point of birth (40 weeks).

${ }^{2}$ The term infant is used to refer to individuals of 44 weeks of gestational age up to one year of age.

${ }^{3}$ Becker 2006, 655

${ }^{4}$ Scott 1999, 90; Meade 2010, 26

${ }^{5}$ E.g. Scott 1999; Lewis 2007; Dommasnes \& Wrigglesworth 2008; Redfern \& Gowland 2012
} 
these burials ${ }^{6}$. These have provided valuable insights into the social and cultural worlds into which these individuals were born, and the perceptions of infants within these societies have been widely discussed ${ }^{7}$. However, skeletal assessment of these young individuals has often concentrated on biological age and sex determination in support of theories of deliberate death and disposal ${ }^{8}$. Yet, skeletal analysis can reveal far more, both about the individuals and their mothers; detailed biological and pathological ${ }^{9}$ assessment furthers our understanding of the complex ways morbidity, mortality and lifestyle factors within past communities affected these perinatal and infant individuals. Thus, this study examines the evidence for growth and health disruption through the analysis of 17 individuals from Piddington, and considers the implications for perinatal/infant and maternal health in this late Iron Age to early Romano-British society. This research aims to highlight the value of palaeopathological evidence, in conjunction with funerary and other contextual evidence, when interpreting perinatal and infant remains from archaeological contexts.

\section{Research Context:}

Since 1979 Piddington has undergone thorough and extensive excavation conducted by the Upper Nene Archaeological Society (U.N.A.S.). These excavations have uncovered a large Roman villa and surrounding estate, with an underlying Iron Age settlement. Piddington, at present, is believed to have undergone seven main phases of occupation, with strong evidence for prehistoric activity on and within the immediate vicinity of the site $^{10}$. Piddington was situated amongst, and en route to, other much larger settlements; Towcester (Lactodorum), Norton (Bannaventa) and Leicester (Ratae) are all nearby, with the Watling Street Roman Road and the Fosse Way accessible (FIG. 1).

\section{(FIG. 1. Map of Piddington location)}

\footnotetext{
${ }^{6}$ Gowland et al. 2014, 69; Millet \& Gowland 2015, 171. E.g. Scott 1999, Pearce 2001, Gowland 2001, Moore 2009

${ }^{7}$ Rawson 1986; Wiedemann 1989; Gowland 2001; Rawson 2003; Redfern 2007; Carroll 2012; Carroll \& Graham 2014

${ }^{8}$ Mays 1993; Mays 2000; Mays \& Eyers 2011; Mays \& Faerman 2001

${ }^{9}$ The term pathological refers to pathology, meaning associated with disease and illness. Thus, pathological assessment means assessment of disease/illness, while pathological lesions (referred to later) are the indicators/lesions identified as sign of disease/illness.

${ }^{10}$ Upper Nene Archaeological Society 2009 Interim Report
} 
Assessment of the site plan shows that the burials all lie within the villa compound, with nine of the perinates/infants being within the main villa structure (FIG. 2). The burials are likely contemporary with the main villa, dating them to between A.D.90 and A.D.190; however, stratigraphic records suggest that some perinates were interred earlier. Evidence of Iron Age features post-dating some of these perinatal burials have also been recorded, with many of the burials sealed by a layer of dark soil known to be of Iron Age date ${ }^{11}$. Miller suggests that although there is no patterning or zoning to the burials, it is notable that the majority are directly between the two larger Iron Age roundhouses, which underlie the main villa structure $^{12}$. Thus, all burials from Piddington are considered to be $1^{\text {st }}$ century A.D. in date, spanning the Late Iron Age and early Roman occupation of the site. Six of the individuals were found to be buried in pairs, although no particular area appears to have been reserved for these infant burials. The undisturbed individuals were all found to be placed in a foetal position ${ }^{13}$ (FIG. 3).

(FIG. 2. Site plan of Piddington with burials marked)

(FIG. 3. Photograph of Burial 24 in fetal position)

\section{Methods:}

This study examines whether growth disruption is identifiable in perinates and infants, and has used existing methods to explore this possibility. It is acknowledged that many of the methods are problematic in accurately determining age-at-death estimates. This is challenging as the paper relies on the comparison of age estimates derived from metric and dental assessment of the individuals. However, this research highlights the potential of these methods to indicate perinatal and infant growth disruption, and hopes further study will help develop more accurate and appropriate methods for analysis.

Assessment of growth disruption was undertaken using two approaches: first to compare age estimates derived from dental development to those derived from metric assessment of skeletal elements, and secondly, by comparing measurements collected from metric assessment against a reference standard. The second of these approaches uses dental development to categorise the individuals by gestational weeks of age, thus enabling the measurements from those individuals to be compared to measurements of the reference individual of the same age.

\footnotetext{
${ }^{11}$ Miller 2012, 12

${ }^{12}$ Miller 2012, 12

${ }^{13}$ Miller 2012, 13
} 
Dental development is considered a more accurate method for estimating gestational age; tooth growth and development is less easily disrupted by external factors and most closely correlated with chronological age ${ }^{14}$. Methods of age-at-death estimation using teeth rely on assessing the stage of development for each tooth ${ }^{15}$. Teeth grow systematically from the tip of the crown down to the root, and this happens at varying yet relatively precise ages for each tooth ${ }^{16}$. The tooth cusps, or developing teeth, recovered from perinatal and infant burials are therefore extremely important for calculating accurate ageat-death estimates. However, tooth cusps are notoriously small and easily lost in the archaeological record. At Piddington, tooth cusps were found to be present in eleven of the burials, although only 10 individuals have been included within dental analysis as Burial 12A and 12B were commingled. This means that 66 percent of the individuals analysed (excluding 12A/B) have tooth cusps present. Tooth cusp development was recorded in accordance with Moorrees et al. ${ }^{17}$ and age estimates attributed using the tooth development atlas developed by AlQahtani et al. ${ }^{18}$. This is the most recent revision of the Moorrees et al. method ${ }^{19}$ and is based on 704 clinical and archaeological individuals of known age-at-death ${ }^{20}$. The major limitation of this method is that it assumes tooth development of the archaeological child and modern reference children are identical ${ }^{21}$. However, this limitation is a feature of all skeletal ageing techniques and Hillson confirms that tooth development varies less between populations than skeletal development ${ }^{22}$. Where tooth cusp development was considered to fall between two developmental stages a midpoint between those two stages was provided. All age estimates were assigned in gestational weeks as is standard practice with perinatal skeletal remains.

To obtain skeletal age estimates, selected long bones and cranial elements were measured in accordance with existing methods ${ }^{23}$. All measurements were taken using digital sliding callipers and the majority

\footnotetext{
${ }^{14}$ Garn et al. 1960, 1053; Smith 1991; Hillson 2005, 207; AlQahtani et al. 2010, 481

${ }^{15}$ Moorrees et al. 1963a; Moorrees et al. 1963b; AlQahtani et al. 2010

${ }^{16}$ Hillson 1979, 147-148; Hillson 2005, 210

${ }^{17} 1963 \mathrm{a} ; 1963 \mathrm{~b}$

${ }^{18} 2010$

${ }^{19}$ Earlier versions of this method include: Schour \& Massler 1941; Massler \& Schour 1944; Ubelaker 1978

${ }^{20}$ AlQahtani et al. 2010, 1

${ }^{21}$ Hillson 2014, 54

${ }^{22} 2014,54$

${ }^{23}$ Fazekas \& Kósa 1978; Scheuer \& Black 2000; Schaefer et al. 2009
} 
were of the long bone diaphyseal lengths to calculate gestational age ${ }^{24}$ (FIG. 4). Metaphyseal ${ }^{25}$ widths of long bones were also recorded. This was to observe whether differences in diaphyseal length and metaphyseal width age estimates could be identified. Growth is widely known to be disrupted when subjected to episodes of stress ${ }^{26}$, and research has also suggested that prioritisation of growth in certain dimensions can be suspected ${ }^{27}$. Thus, metric assessment of these two dimensions was analysed in order to examine whether inconsistencies and differences between age estimates - suggestive of growth disruption - could be identified. The metaphyseal width measurements were taken at the distal ${ }^{28}$ ends of the long bones (FIG. 5). Measurements were also taken of cranial elements, in particular those of the pars basilaris $^{29}$, a bone at the base of the cranium forming part of the foramen magnum. Due to the changes in morphology, and thus the measurements obtained, the pars basilaris is considered to be indicative of certain age thresholds ${ }^{30}$.

(FIG. 4. Photograph of femur showing diaphyseal length measurement)

(FIG. 5. Photograph of femur showing metaphyseal width measurement)

Linear regression equations, developed by Scheuer, Musgrave and Evans ${ }^{31}$, were used to calculate age estimates based on long bone diaphyseal length measurements. This method was employed as it is based on clinical data of known age-at-death individuals ${ }^{32}$. In addition, some of the Piddington individuals had

\footnotetext{
${ }^{24}$ For information of bone development and ossification see Scheuer \& Black 2000, 18. Diaphyseal length refers to the length of the diaphysis or 'shaft' of the long bone (White \& Folkens 2005). The diaphysis is the primary ossification centre of the bone and what is commonly found and identified in perinatal and infant burials. At this young age our bones have not yet completed growth and thus our epiphyses (ends of bones), which develop and ossify separately to the diaphysis, have not yet fused together with the diaphysis to make a complete long bone.

${ }^{25}$ Metaphyseal refers to the end of the long bone diaphysis or shaft. The metaphysis contains the growth plate and thus is the point at which most growth occurs during infancy and childhood. The metaphysis is highly vascular and susceptible to changes when disruption in growth occurs.

${ }^{26}$ Tanner 1978; Bogin 1999; Bogin \& Loucky 1997; Bogin et al. 2002; Ruff et al. 2013

${ }^{27}$ Dancause et al. 2012; Shrader \& Zeman 1973

${ }^{28}$ Distal is a positional term, referring to the end of the long bone furthest from the cranium, and closest to the feet.

${ }^{29}$ Fazekas \& Kósa 1978, 46

${ }^{30}$ Scheuer \& Black 2000, 57-58

${ }^{31} 1980$

${ }^{32}$ Scheuer et al. 1980, 258
} 
long bone diaphyseal length measurements that were over the upper bounds of those given by Fazekas and $\mathrm{Kósa}^{33}$, but considerably under the measurements recorded by Maresh ${ }^{34}$. Thus, this method proved useful in determining more specific age estimates for those which fell between 40 and 46 gestational weeks ${ }^{35}$. The age estimates derived from this method of assessment have been used in Figure 6 to compare differences in age estimates derived from dental and skeletal assessments, and in Figures 7, 8 and 10 where measurements derived from this method have been used as reference points against which data from the Piddington individuals have been plotted.

Reference data published by Fazekas and $\mathrm{Kósa}^{36}$ has been used in consideration of the pars basilaris (FIG. 11) and when comparing long bone diaphyseal lengths and metaphyseal widths (FIG. 9i and 9ii). This is because this is still the only published data which details averaged measurements, for individuals aged between 30 and 40 gestational weeks at two week intervals, for these skeletal dimensions. This method has not been used to estimate age-at-death from skeletal measurements, but is included as a reference sample.

The primary limitation of using these various methods is that their results rely on different study populations. This means the Piddington individuals have been aged dentally in comparison with European $19^{\text {th }}$ and $20^{\text {th }}$ century individuals and aged skeletally in comparison to European $20^{\text {th }}$ century individuals. This range of comparative material means that differences between age estimates, and variation from the reference data, may be expected. However, evidence from living populations suggests that early development and growth is relatively similar between populations, as long as the environment is optimal ${ }^{37}$. Consequently, differences between growth and age estimates identified in such young individuals are considered to be indicative of health stress $^{38}$.

Assessment of the presence and characteristics of pathological lesions was undertaken macroscopically. The location of the pathological change, its extent, severity and nature (bone formation/destruction) and

\footnotetext{
331978

341970

35 This method has only been used to calculate age estimates up to 46 weeks of gestational age as this was the maximum age of the individuals used in the original study.

361978

${ }^{37}$ Ruff et al. 2013, 30

${ }^{38}$ Ruff et al. 2013, 30
} 
the type of new bone formed (woven/lamellar; pitted/striated/spiculated ${ }^{39}$ ) were all documented descriptively and photographically. Pathological changes to long bones, and the ectocranium ${ }^{40}$ and endocranium $^{41}$, were recorded in detail. The identification and assessment of pathological indicators in these very young individuals provides further challenges and limitations; distinguishing between normal growth and pathological new bone formation has been, and remains, an ongoing area of discussion ${ }^{42}$. Bone has a limited response to health stress: it can either form new bone or resorb bone. When bone forms in response to infection or dietary deficiency, it is sometimes difficult to distinguish it from normal bone growth, which is constant and rapid in perinatal and infant individuals ${ }^{43}$. While caution must be exercised when recording pathology in such young individuals, the findings of this study suggests that severe pathological bone growth can be differentiated from normal growth processes on the remains from Piddington. The author has, to date, analysed the perinatal remains of 434 individuals and thus the pathologies observed at Piddington are contex tualised against an extensive knowledge of the appearance of normal perinatal growth. The pathological lesions from Piddington were also examined by another experienced bioarchaeologist ${ }^{44}$.

\section{Results:}

Figure 6 indicates that all age estimations derived from tooth development are older than those estimated from metric assessment. The degree to which the age estimates differ is variable; eight of the individuals have at least a four-week difference between their tooth and metric age estimations, with a difference of 15 weeks for Burial 19. Even when taking into consideration a margin of error for these methods, there is still a considerable discrepancy between some of the age estimations given. These results suggest that

\footnotetext{
${ }^{39}$ Ortner 2003, 45-64 (Chapter 4). Identification and description of pathological lesions were recorded in accordance with Ortner (2003). Woven bone indicates an active lesion whereas lamellar bone indicates healing. The terms pitted, striated and spiculated can also indicate whether a lesion is active or healed, but also provide an indication as to the nature of the bone changes (whether bone is resorbing, forming, or existing bone is changing in structure). This is important for distinguishing the possible aetiologies (causes) of these lesions.

${ }^{40}$ The ectocranium is the outer surface of the cranial vault.

${ }^{41}$ The endocranium is the internal, concave surface of the cranium. This internal surface comes into contact with many soft tissues of the cranium including the blood vessels that supply the brain and the dura mater, a membrane which protects the brain.

${ }^{42}$ Ortner 2003, 15

${ }^{43}$ Ortner 2003, 45

${ }^{44}$ Dr. Rebecca Gowland has also observed the pathological lesions present on these remains.
} 
over half of the Piddington individuals may have experienced growth disruption. Burials 12A and 12B have been excluded from analysis due to comingling of the dental and skeletal remains.

\section{(FIG. 6. Graph displaying dental and skeletal age estimates for each individual)}

Analysis of femoral and humeral diaphyseal length measurements against reference data, calculated using Scheuer et al. ${ }^{45}$, supports the suggestion that growth was disrupted. Using the linear equations given for femoral and humeral diaphyseal lengths, reference measurements have been plotted to indicate the expected length of these long bones for individuals aged between 36 and 46 gestational weeks. Error bars have been given for these measurements, $+/-2.08 \mathrm{~mm}$ for the femora and $+/-2.33 \mathrm{~mm}$ for the humeri. Diaphyseal length measurements recorded from the Piddington individuals have been plotted in accordance with their dental age. Error bars have been included for the dental age estimations of the Piddington individuals in accordance with those stated in AlQahtani et al. ${ }^{46}$.

(FIG. 7. Graph displaying femoral length measurements plotted against linear equation data)

(FIG. 8. Graph displaying humeral length measurements plotted against linear equation data)

Figures 7 and 8 demonstrate that all of the individuals from Piddington with dental age estimates available fall considerably below the expected attainment of long bone diaphyseal length growth, if the dental age is presumed accurate. However, when the error levels of both the dental age estimates and the diaphyseal length measurements are considered, only two individuals, for both the femoral and humerus analysis, can be interpreted as showing significant differences between dental and skeletal estimates. Although these may be the only two individuals that can be definitively identified as showing growth disruption, a couple of other individuals, estimated dentally to be 46 weeks of age, intercept the reference measurements at the tail end of their error bars, also suggesting growth disruption.

Figures 9i and 9ii compare diaphyseal length and metaphyseal width for the femora and humeri. These measurements have been plotted against reference measurements for a 36, 38 and 40 gestational week old

\footnotetext{
451980

${ }^{46}$ 2010: +/- 2 weeks for those aged 40 weeks and +/- 12 weeks for those aged 46 weeks and above. For Burial 4 , dentally aged as 43 weeks, a +/- of 7 weeks has been given. This is because the dental development age was the midpoint of two age categories, thus, the midpoint of the error ranges has been given also.
} 
individual ${ }^{47}$. The symbol used to plot each of the individuals is representative of their tooth age estimate ${ }^{48}$. This enables consideration of where the individuals would be expected to be approximately plotted; if dental and skeletal age estimates were the same, the individuals should align closely with the reference data plotted. Two points have been plotted for some of the burials, this is due to both left and right measurements being available for recording.

(FIG. 9i. and 9ii. Graphs displaying femoral length plotted against femoral width, and humeral length plotted against humeral width.)

Both Figures 9i and 9ii display similar patterns of growth disruption for the femora and humeri. Burials 2 and 21 align closely with the reference measurements for the femora. By contrast the femoral measurements of Burial 4, 5, 7 and 24 indicate that growth has been disrupted. Burials 5, 7 and 24 are all suggested to be 46 weeks of gestational age, yet there is around a $12 \mathrm{~mm}$ difference between minimum and maximum femoral length of these individuals and $4.5 \mathrm{~mm}$ difference between minimum and maximum metaphyseal width. Both Burial 7 and Burial 24 have femoral lengths well below what is expected, whereas Burial 5 has femoral length measurements more consistent with a 46-week-old individual, yet has metaphyseal measurements which fall on and below the 38 -week reference point.

For the humeral measurements there are similar patterns of growth disruption, with Burials 7, 17, 18 and the left humerus of Burial 24, again failing to attain their expected diaphyseal lengths. The right humerus of Burial 24, however, aligns with the reference measurements, despite falling below what would be expected of a 46-week old individual. This bilateral difference is also mirrored in the femoral measurements. A greater discrepancy between the bilateral measurements can be seen most in Burial 24, although Burial 5 also appears to show bilateral differences in measurements. This may indicate that not only is growth being disrupted between dimensions but also between sides of the body.

Overall, there is a greater range of growth disruption present in the femora than in the humeri. Interestingly, the femora and humeri of the same individual are not always disrupted correspondingly or to the same degree, suggesting that growth disruption is not equal throughout the skeleton and that individual elements can be affected in isolation. To consider differences between upper and lower limbs

\footnotetext{
${ }^{47}$ Fazekas and Kósa 1978

${ }^{48}$ A circle indicates the individual is 40 gestational weeks old (GWO), a square $43 \mathrm{GWO}$, a triangle 46 (GWO) and a diamond 58 (GWO).
} 
further, total lower limb length (femoral + tibial diaphyseal length) was plotted against total upper limb length (humeral + radial diaphyseal length). Reference measurements were also plotted for comparison. Eight individuals from Piddington had all four skeletal elements from one side available for assessment, with five individuals having both left and right elements present. Results (FIG. 10) suggest that growth to the lower limb is being disrupted more with the average difference between Piddington and reference measurements being greater in the lower limb. However, statistical analysis revealed no significant difference for the upper or lower limb combined measurements for those aged 40 gestational weeks when compared to the reference measurements. For those aged 46 weeks however, a significant difference was found for both the upper and lower limb combined totals when compared to the 46-week reference measurement. No statistical analysis could be undertaken of Burial 19 (58 gestational weeks based on dental development) as no reference standard exists for this age.

\section{(FIG. 10. Graph displaying comparison of upper and lower limb total lengths)}

Metric assessment of cranial bones indicated that growth disruption was not limited to the limb bones. Figure 11 shows that there is extensive growth disruption to the pars basilaris in the majority of the individuals, despite this typically being the most reliable cranial element for estimating age at death ${ }^{49}$. The pars basilaris of Burial 24 aligns closely with the reference measurements of Fazekas and Kósa ${ }^{50}$, but suggests an age estimate over 6 weeks younger than that generated from the tooth development. Burial 2 displays the most anomalous measurement, with the length of this element substantially larger than what is typical of a 40 -week-old individual. Burial 6, has a width measurement far beyond that expected, yet almost exactly aligns with the reference measurement in terms of length. In contrast, Burials 4,7 and 18 all have measurements which fall short, both in terms of length and width, for their age estimates; these burials have length measurements suggestive of 38 weeks or less meaning there is a five-week difference between age estimates for Burial 4 and at least an eight-week difference for Burials 7 and 18.

\section{(FIG. 11. Graph displaying pars basilaris width vs length)}

Pathological lesions were identified on 14 of the perinates. While these lesions varied in location (FIG. 12), severity and prevalence, most lesions were found to be cranial. Overall, 14 out of 17 perinates demonstrated new bone formation on the endocranial surface of the cranial bones. The three remaining

\footnotetext{
${ }^{49}$ Scheuer \& Black 2000, 57-58

501978
} 
burials had no cranial elements to assess. The most commonly affected cranial element was found to be the endocranial surface of the frontal bones (11 individuals), followed by the occipital squama (nine individuals) and then the parietal bones (eight individuals).

\section{(FIG. 12. Pie chart showing the \% of pathologies identified)}

Both woven $^{51}$ (active) and lamellar (healed) new bone formation was identified on the cranial bones of all 14 perinates with endocranial lesions. In those individuals where lamellar bone is present the bone often appeared as a plateau, raised above the endocranial surface and with a 'web-like' appearance (FIG. 13i). Many of these lesions, found particularly on the frontal and parietal bones, also showed vascular impressions running through the new bone deposits. On the occipital squama woven bone was more typically present. These deposits were more porous in nature and often appeared to be in association with vascular activity; all the lesions were found within the sagittal and transverse sulci of this element (FIG. 13ii). A further type of bone deposit was also identified at the sutural edges of the cranial vault elements. These bone deposits were irregular in form, with lattice-like organisation and were identified primarily as lamellar bone (FIG. 13iii).

(FIG. 13i. 13ii. and 13iii. Photographs displaying endocranial lesions)

Ectocranial surface changes were only identified in Burial 6. The characteristics of the lesions were similar to those found on the endocranial surface; appearing raised from the original cortical surface and 'web-like' in appearance (FIG. 14). More than one layer of bone was deposited, suggesting a recurrent bone response and healing.

(FIG. 14. Photograph of ectocranial lesions)

Pathological changes were also identified on the limb bones, particularly those of the lower limb where new bone formation was identified on eight of the perinates. The tibiae were the most commonly affected of the long bones and displayed additional layers of porous, woven new bone formation (FIG 15i and 15ii). These were distinct additional layers of bone on top of the original cortical surface which gave them an overall 'thickened' morphology.

${ }^{51}$ Woven bone is occasionally referred to as fiber bone (Ortner 2003, 19) 
(FIG. 15i. and 15ii. Photographs of long bone pathological lesion)

\section{Discussion:}

Pathological and metric assessment indicates that the individuals from Piddington experienced severe episodes of poor health that resulted in growth disruption. Despite the limitations of existing methods of assessment, over $80 \%$ of the individuals showed evidence of pathology and many have measurements that were inconsistent with growth standards. A correlation between growth and health disruption was identified; health stress, affecting overall well-being, is likely the major factor affecting normal growth.

Metabolic stress (malnutrition) is the most probable cause of the growth and health disruption identified. The lack or limited intake of various nutrients and vitamins, can cause both acute and chronic changes in the human skeleton. Vitamin C and D deficiencies can affect growth and development of the skeleton; lack of vitamin $\mathrm{C}$ results in defective osteoid formation ${ }^{52}$ (development of new bone cells), whilst vitamin D deficiency affects the calcification of bone ${ }^{53}$. Enlarged or widened and porous metaphyses, identified in some of the individuals (FIG. 9i and 9ii), is also an indication of vitamin D deficiency, in which cartilage at the growth plates does not mineralise properly ${ }^{54}$. Metaphyseal changes can also indicate the presence of vitamin $\mathrm{C}$ deficiency as widening at the metaphyses could suggest chronic bleeding at the joints ${ }^{55}$. Lack of vitamin $\mathrm{C}$ can result in blood vessels becoming fragile and easily ruptured ${ }^{56}$. This can lead to haemorrhaging, including in the vessels supplying the metaphyses, but particularly within the cranium ${ }^{57}$. The Piddington perinates exhibited evidence of endocranial lesions, suggestive of cranial haemorrhaging ${ }^{58}$ and chronic bleeding ${ }^{59}$. Lesions associated with cranial haemorrhaging are typically found around meningeal grooves, on the frontal bones and at the cruciate eminence of the occipital bone,

\footnotetext{
52 Brickley \& Ives 2006, 163

${ }^{53}$ Lewis 2007, 121

${ }^{54}$ Roberts \& Manchester 2010, 237-238

55 Aufderheide \& Rodriguez-Martín 2008, 311

${ }^{56}$ Brickley \& Ives 2006, 163; Ortner \& Ericksen 1997, 213

${ }^{57}$ Roberts \& Manchester 2010, 235

${ }^{58}$ Brickley \& Ives 2006, 168

${ }^{59}$ Ortner et al. 1999, 328
} 
where they present a web-like appearance ${ }^{60}$. Although their exact aetiology is debated ${ }^{61}$, other possible causes are meningitis, anaemia and venous drainage disorders ${ }^{62}$.

The presence of these pathological lesions in such young individuals are suggestive of a poor intrauterine environment. Maternal malnutrition, either as a result of limited access to food sources or infection, has been identified as causing and exacerbating conditions such as anaemia and maternal haemorrhage, and is known to restrict fetal growth and development ${ }^{63}$. Critically, these conditions can often lead to more unfortunate outcomes such as low birth weight, preterm birth and even birth defects ${ }^{64}$. Although at Piddington no adult remains have been found within the Iron Age or Roman contexts, disruption to perinatal/infant growth and health indicates that the mother was facing adverse conditions. There is a constant interaction between the fetus, placenta and mother ${ }^{65}$, with the mother and placenta typically acting as barriers and regulators, ensuring that the fetus is receiving the highest-level of nutrition that the mother can provide ${ }^{66}$. When this nutrient transfer is disrupted, in particular during periods of nutritional deficiency experienced by the mother, these deficiencies become expressed in the fetus. The fetus will be unable to accumulate any stores of nutrients such as vitamin $C$, vitamin D, calcium and iron, which are vital in the initial stages of life outside the womb ${ }^{67}$. Therefore, the indication of metabolic stress presented on the skeletal remains of perinatal/infant individuals suggests that maternal health and nutrition was reduced for a sustained period of time so that the mother could no longer act as an effective barrier to protect them. This is corroborated by the fact that vitamin C deficiency is considered to only be skeletally identifiable after at least six months of the vitamin being absent or reduced in the $\operatorname{diet}^{68}$. Therefore, evidence from the Piddington remains suggests either chronic under-nutrition and lack of fresh fruits and vegetables, or vitamin $\mathrm{C}$ absorption was being prevented due to maternal illness and infection. Parasitic infections are known to cause chronic disease but can often manifest as a nutritional deficiency ${ }^{69}$, causing severe changes in fetal development, as the parasite can prevent nutrients and vitamins being absorbed by

\footnotetext{
${ }^{60}$ Lewis 2007, 141; 2004, 82

${ }^{61}$ Lewis 2007, 82

${ }^{62}$ Lewis 2007, 141; 2004, 93

${ }^{63} \mathrm{Wu}$ et al. 2012, 4

${ }^{64} \mathrm{Wu}$ et al. 2012, 4

${ }^{65}$ Harding \& Johnston 1995, 539

${ }^{66}$ Barker 2012. 187

${ }^{67}$ Lewis 2007, 98

${ }^{68}$ Brickley \& Ives 2006, 164

${ }^{69}$ Roberts \& Manchester 2010, 218
} 
the mother. Furthermore, nutritional deficiency is also known to cause intrauterine growth restriction $(\mathrm{IUGR})^{70}$.

The predisposition of foetuses to such deficiencies can have long-term implications for health and disease $^{71}$. Many significant studies into the long-term health consequences of a poor in utero environment have revealed that major health problems in older adulthood are a result of reduced circumstances during growth and development, in both the pre-natal and post-natal period ${ }^{72}$. From the Developmental Origins of Health and Disease hypothesis $(\mathrm{DOHaD})^{73}$ it is known that gene expression can alter in response to a variety of stressors ${ }^{74}$. Were the mothers from Piddington predisposed to a reduced health status as a result of their own in utero development and the life course of their own mothers? Epidemiological studies have suggested a link between IUGR and chronic metabolic disease in both children and adults ${ }^{75}$. As a result, the chronic metabolic stress inferred from the perinatal remains may be a result of long-term, multigenerational exposure to stress, in particular under-nutrition. Furthermore, studies ${ }^{76}$ have demonstrated that there was a marked reduction in health during the transition from Iron Age to Roman life, particularly within rural settlements. Consequently, the health stress identified at Piddington must be considered within the changing landscape of Britain and, may in fact, be representative of a population transitioning from an Iron Age to Romanised lifestyle. In particular, an increase in metabolic stress, vitamin C and D deficiency, during the Iron Age to Roman transition was identified in Dorset ${ }^{77}$. This again may suggest that the pathological lesions identified on the Piddington remains, suspected to show evidence of metabolic stress, may demonstrate a similar pattern, and may even be expected for such a population.

Metric assessment of the Piddington burials also shows clear disruption to growth in some individuals, with the suggestion that others were also likely affected. The lower limbs were found to have a bigger difference to the reference population, in comparison to the upper limbs, suggesting growth was more disrupted in the femora and tibiae. However, the tibiae are known to be the most variable and susceptible

\footnotetext{
${ }^{70} \mathrm{Wu}$ et al. 2012, 4; Armelagos et al. 2009, 265

${ }^{71}$ Barker 1997; Gowland 2015

${ }^{72}$ Armelagos et al. 2009, 261; Heinke \& Kuzawa 2008, 538

${ }^{73}$ Barker 1997

${ }^{74}$ Barker 1997; Barker 2012; Non et al. 2016, 84

${ }^{75}$ Wu et al. 2012, 4-5; Abu-Saad \& Fraser 2010

${ }^{76}$ Redfern et al. 2012 ; Redfern \& DeWitte 2011; Griffin et al. 2011

${ }^{77}$ Redfern et al. 2012
} 
to growth disruption when exposed to stress ${ }^{78}$. Therefore, these greater differences in the lower limbs may be as a result of greater variation within the tibial measurements. However, it must also be considered that during fetal and infant development, $87 \%$ of growth is prioritised to the cranium ${ }^{79}$. Consequently, the fact that all limbs individually and combined show disruption, may be a result of a general prioritisation of resources towards cranial, rather than infracranial growth. In addition, if the pathological lesions and the illness/conditions these individuals may have been facing are also considered, general disruption to growth is expected. Very little difference in bilateral measurements was observed. However, Burial 24 does show the most extreme differences in measurement, and interestingly this individual does have some of the more severe pathology. This asymmetry could be considered to be a further indicator of growth disruption ${ }^{80}$.

Multiple possibilities for the cause of endemic and long-term health stress, must be considered. There is a complicated relationship between the health stress and pathological lesions identified, and the social and physical environment that these perinates, infants and their mothers experienced ${ }^{81}$. As Gowland ${ }^{82}$ states, $^{2}$ cultural practice can affect the exposure and response to health stress within and between populations, meaning depending on who you are within a society, you may be differentially exposed to both health risks and treatment. Therefore, understanding the pathological lesions and growth changes identified on the perinates and infants from Piddington pivots around a discussion of who these mothers were, their social status and their position within Iron Age and Roman society. With no adult remains having yet been excavated, it is impossible to understand the true dynamic of the community at Piddington, or why maternal health appears to have been so compromised. However, consideration as to whether these mothers were young or old, high or low status, native Iron Age peoples or 'Roman' enables reflection of some of the various factors that may have affected perinatal, infant and maternal life at Piddington.

In both Iron Age and Roman communities in Britain, multiple people would have been present and working in the settlement in addition to the inhabitants and owners. Servants and slaves were an integral part of the social organization of Iron Age and Romano-British communities, particularly on agricultural

\footnotetext{
${ }^{78}$ Smith \& Buschang 2004, 655

${ }^{79}$ Cameron \& Bogin 2012, 351

${ }^{80}$ Cameron \& Demerath 2002

${ }^{81}$ Gowland 2004, 135

${ }^{82} 2004,135,137$
} 
and villa estates ${ }^{83}$. Webster ${ }^{84}$ suggests that positions of servitude and slavery were common amongst these communities and, even though little archaeological evidence has been found to substantiate this, it is commonly accepted that there was a large network in the trading of people and slaves within Britain before the Roman conquest. Therefore, it is plausible that these individuals were present at Piddington; if these perinatal and infant remains are those of the lesser, lower ranks of women living and working on site, this may explain the high levels of pathological conditions being identified. The extensive evidence of metabolic stress may indicate limited access to certain food types, or even that these women were engaged in work that involved limited exposure to sunlight (vitamin D). Social inequality is known to increase susceptibility to poor health and disease ${ }^{85}$. Thus, a reduced social status would mean a limited access to high quality food, harsher working and living environments and limited access to medical care. However, these perinatal and infant remains may equally be those of the high status women at the site. If this is the case, it suggests that maternal health was reduced regardless of social position. This may indicate a more general limited availability of food, some form of endemic infection, or even cultural practices of pregnant mothers such as restrictive diets and avoidance of sunlight.

Furthermore, it must also be considered whether these women and mothers were native Iron Age people or 'Romans'. As these burials are from the $1^{\text {st }}$ century A.D. it must be remembered that this is a period of great transition, especially at Piddington, where the influx of the Roman army would potentially have led to wide-scale social and cultural changes ${ }^{86}$. From modern clinical studies, it has been identified that any form of stress, be that physical, mental, social or cultural can lead to growth disruption ${ }^{87}$. Thus, the pathological lesions identified might be a result of the mother experiencing a multitude of stressors simultaneously.

Regardless of social status, working or living conditions, it is vital to consider the precarious nature of pregnancy for any mother, even today. Today, stressors experienced by the mother and developing child alike during the in utero period are known to cause a multitude of both short-term and long-term

\footnotetext{
${ }^{83}$ Webster 2005, 165

842005,169

${ }^{85}$ Griffin et al. 2011, 533

${ }^{86}$ Research (e.g. Refern \& DeWitte 2011) has determined that the period of transition, from Iron Age to Roman, was detrimental to health.
}

${ }^{87}$ Eg. Barker 2012; Sandman et al. 2016; Thorsell \& Nätt 2016 
consequences to the health of the individual ${ }^{88}$. Lifestyle factors are primarily the cause of growth disruption, changes to gene expression and overall well-being. However, the fragility of fetal life and growth remains even today ${ }^{89}$. The evidence indicates that these 17 individuals from Piddington represent 'natural' deaths. It is likely that there were high mortality rates amongst young infants in Iron Age and Romano-British contexts ${ }^{90}$; estimates suggest between $20-40 \%$ of infants would not survive to one year of age $^{91}$. With a prolonged reduction in health status during in utero life, the likelihood of survival after birth is decreased further, especially if the mother was weakened from the birth process, unable to feed the child or potentially died herself in childbirth. Paradoxically, the individuals from Piddington, although showing extensive pathological lesions, also show signs in many cases of healing, or a recurrent response by the bone, indicating multiple episodes of poor health. Although this indicates greatly reduced maternal health status, it also suggests that the perinatal and infant individuals, as well as the mothers, were able to endure health stresses too.

The mortality of these perinatal individuals from Piddington must ultimately be considered in terms of poor maternal health. Such severe pathological lesions and irregular growth patterns indicate that maternal health greatly affected the lives of these perinatal individuals, and ultimately led to their premature deaths. With such high rates of infant mortality, death was a common experience within such societies; that is not to say that it was expected or attitudes towards death were indifferent, but simply death was a part of life and consequently evidence of infant death is not surprising. This likelihood of death combined with evidence of such chronic and endemic health reduction suggests that interpretations of infanticide at Piddington are unlikely. The burial of perinates and infants within a domestic setting, and not within a formal cemetery, is a common practice within Iron Age and Roman contexts ${ }^{92}$. The burial of infants close to, within and under settlements and dwellings has been argued by some to show deviant, hidden burial, suggestive of 'foul play' and the deliberate killing of individuals based on sex or disability ${ }^{93}$. However, many scholars have rejected these notions, instead considering the 'spiritual' infant and its place within the community ${ }^{94}$. Burial of infants within the domestic context may be nothing more

\footnotetext{
${ }^{88}$ Hoffman 2016, 655

${ }^{89}$ National Health Service Still Birth Statistics

${ }^{90}$ Carroll 2011, 102-103; Carroll 2012, 42; Millet \& Gowland 2015, 173; Pearce 2001, 125; Wiedemann 1989, 11

${ }^{91}$ Carroll 2011, 103; Hopkins 1983, 225

${ }^{92}$ Scott 1999, 90; Beilke-Voigt 2008; Moore 2009, 33

${ }^{93}$ Heneage Cocks 1921; Molleson 1999; Mays 1993; Mays 2000; Mays \& Faerman 2001; Mays \& Eyers 2011

${ }^{94}$ Pearce 1999; Pearce 2001; Scott 1991; Gowland \& Chamberlain 2002; Moore 2009; Gowland et al. 2014; Millet

\& Gowland 2015
} 
than simply pragmatic. It is known that infants are afforded different burial 'rites' to those of older children and adults; perinates and young infants were often not considered to be a part of the community until a certain age threshold had been attained ${ }^{95}$. The burial rites of these perinates at Piddington suggest careful placement of the individuals in many instances (seen in FIG. 3).

\section{Conclusion:}

Detailed analysis of the perinatal burials from Piddington reveals a wealth of biological and pathological information. This evidence is for understanding these young deaths, not simply in terms of casual or careless disposal, but as providing insights into the unpredictable and tough lives of expectant mothers 2000 years ago. Metric and pathological assessment suggests evidence of disruption to growth and health in these individuals. The implications of these findings indicate intrauterine life and survival was precarious, suggesting that the health status of the mothers was greatly reduced and ultimately led to the shortened lives of these individuals. Therefore, it can be suggested that there is no indication of deliberate killing, thoughtless disposal or lack of care surrounding these burials. These individuals instead died weakened and ill, nothing more than the unlucky victims of chronic suffering.

\section{Acknowledgements:}

I wish to thank Dr Becky Gowland and Professor Charlotte Roberts for their guidance and constructive comments on an earlier version of this article. I also wish to thank Professor Christopher Knüsel who inspired and developed my interest in infant burials and who supervised the initial data collection for this project. I would warmly like to thank Roy and Liz Friendship-Taylor, site directors at Piddington Excavation, for their constant support, interest and help with this research and for allowing me to work with the Piddington perinates. I wish to also thank the AHRC for funding this research [Grant Number: AH/K502996/1].

Department of Archaeology, Durham University, DH1 3LE, UK

Email: c.m.hodson@durham.ac.uk

${ }^{95}$ Scott 1999, 1 


\section{Bibliography:}

Abu-Saad, K. and Fraser, D. 2010; Maternal nutrition and birth outcomes. Epidemiological Review, Vol. 32: $5-25$.

AlQahtani, S. J. Hector, M. P. and Liversidge, H. M. 2010; The London Atlas of Human Tooth Development and Eruption. American Journal of Physical Anthropology, Vol. 142: 481-490.

Armelagos, G. J., Goodman, R. H., Harper, K. N., and Blakey, M. L. 2009; Enamel hypoplasia and early mortality: bioarchaeological support for the Barker hypothesis. Evolutionary Anthropology 18, 261-271.

Aufderheide, A. C. \& Rodriguez-Martín, C. 2008; The Cambridge Encyclopedia of Human

Palaeopathology. Cambridge: Cambridge University Press.

Barker, D.J. 1997; Maternal nutrition, fetal nutrition, and disease in later life. Nutrition, Vol. 13:807-13.

Barker, D. J. 2012; Developmental origins of Chronic Disease. Public Health, Vol. 126: 185-189.

Becker, M. J. 2006; The Archaeology of Infancy and Childhood; Integrating and Expanding Research into the Past. American Journal of Archaeology, Vol. 110, No.4: 655-658.

Beilke-Voigt, I. 2008; Burials of Children in Houses and Settlements during the Roman Iron Age and Early Medieval Period in Northern Germany and Denmark. In L. H. Dommasnes and M. Wrigglesworth (Eds.) Children, Identity and the Past. Newcastle: Cambridge Scholars Publishing: 16-35.

Bogin, B. 1999; Patterns of Human Growth, 2nd Ed. Cambridge: Cambridge University Press.

Bogin, B. and Loucky, J. 1997; Plasticity, Political Economy, and Physical Growth Status of Guatemala Maya Children Living in the United States. American Journal of Physical Anthropology, Vol. 102: 17-32.

Bogin, B. Smith, P. Orden, A. B. Varela Silva, M. I. and Loucky, J. 2002; Rapid Change in Height and Body Proportions of Maya American Children. American Journal of Human Biology, Vol. 14: 753-761. 
Brickley, M. and Ives, R. 2006; Skeletal Manifestations of Infantile Scurvy. American Journal of Physical Anthropology, Vol.29: 163-172.

Cameron, N. and Bogin, B. 2012; Human Growth and Development (2 $2^{\text {nd }}$ Edition). London: Elsevier.

Cameron, N. and Demerath, E. W. 2002; Critical Periods in Human Growth and Their Relationship to Diseases of Aging. Yearbook of Physical Anthropology, Vol. 45: 159-184.

Carroll, M. 2011; Infant death and burial in Roman Italy. Journal of Roman Archaeology, Vol. 24: 99120.

Carroll, M. 2012; 'No part in earthly things'. The Death, Burial and Commemoration of Newborn Children and Infants in Roman Italy. In M. Harlow and L. Larsson Loven (Eds.) Families in the Roman and Late Antique World. London: Continuum: 41-63.

Carroll, M. and Graham, E-J. (Eds.) 2014; Infant Health and Death in Roman Italy and Beyond. Journal of Roman Archaeology Supplementary Series Number 96.

Dancause, K. N. Cao, X. J. Veru, F. Xu, S. Long, H. Yu, C. Laplante, D. P. Walker, C. D. and King, S. 2012; Prenatal and Early Postnatal Stress Exposure Influences Long Bone Length in Adult Rat Offspring. American Journal of Physical Anthropology, Vol. 149: 307-311.

Dommasnes, L. H. and Wrigglesworth, M. (Eds.) 2008; Children, Identity and the Past. Newcastle: Cambridge Scholars Publishing.

Fazekas, I. G. and Kósa, F. 1978; Forensic Foetal Osteology. Budapest: Academic Press.

Garn, S. M. Lewis, A. B. and Polacheck, D. L. 1960; Interrelations in dental development. I. Interrelationships within the dentition. Journal of Dental Research, Vol. 39: 1049-1055.

Gowland, R. L. 2001; Playing Dead: Implications of mortuary evidence for the social construction of childhood in Roman Britain. In D. Davis, A. Gardner and K. Lockyear (Eds.) TRAC 2000. Oxford: Oxbow: 152-168. 
Gowland, R.L. 2004; The social identity of health in late Roman Britain. In B. Croxford, H. Eckardt, J. Meade and J. Weekes (Eds.) TRAC 2003. Oxford: Oxbow: 135-146

Gowland, R. L. 2015; Entangled Lives: Implications of the Developmental Origins of Health and Disease Hypothesis for Bioarchaeology and the Life Course. American Journal of Physical Anthropology, Vol. 158, No. 4: 530-540.

Gowland, R. L. and Chamberlain, A. T. 2002; A Bayesian Approach to Ageing Perinatal Skeletal Material from Archaeological Sites: Implications for the Evidence for Infanticide in Roman-Britain. Journal of Archaeological Science, Vol. 79: 677-685.

Gowland, R. L., Chamberlain, A. T., Redfern, R. C. 2014. On the brink of being: re-evaluating infant death and infanticide in Roman Britain, in M. Carroll and E-J. Graham (eds), Infant Health and Death in Roman Italy and Beyond, Journal of Roman Archaeology Supplementary Series 98, 69-88.

Griffin, R. Pitts, M. Smith, R. and Brook, A. 2011; Inequality at Late Roman Baldock, UK. The Impact of Social Factors on Health and Diet. Journal of Anthropological Research, Vol. 67, No.4: 533-556

Harding, J. E. and Johnston, B. M. 1995; Nutrition and Fetal Growth. Reproduction, Fertility and Development, Vol. 7, No. 3: 539-548.

Heinke, D. and Kuzawa, C. W. 2008; Self-Reported Illness and Birth Weight in the Philippines: Implications for Hypotheses of Adaptive Fetal Plasticity. American Journal of human Biology, Vol. 20: 538-544.

Heneage Cocks, A. 1921; A Romano-British homestead in the Hambleden Valley, Buckinghamshire. Archaeologia 71:141-66.

Hillson, S. W. 1979; Diet and Dental Disease. World Archaeology, Vol. 11, No. 2, Food and Nutrition: 147-162.

Hillson, S. W. 2005; Teeth (Second Edition). Cambridge: Cambridge University Press. 
Hillson, S. W. 2014; Tooth Development in Human Evolution and Bioarcheology. Cambridge: Cambridge University Press.

Hoffman, C. 2016; Stress, the Placenta, and Fetal Programming of Behaviour: Genes' First Encounter With the Environment. American Journal of Psychiatry, Vol.173: 655-657.

Hopkins, K. 1983; Death and Renewal. Cambridge: Cambridge University Press.

Lewis, M. E. 2004; Endocranial Lesions in Non-Adult Skeletons: Understanding their Aetiology. International Journal of Osteoarchaeology, Vol. 14: 82-97.

Lewis, M. E. 2007; The Bioarchaeology of Children: Perspectives from Biological and Forensic Anthropology. Cambridge: Cambridge University Press.

Maresh, M. M. 1970; Measurements from roentgenograms. In R. W. McCammon (Ed.) Human Growth and Development. Springfield: C. C. Thomas: 157-200.

Massler, M. and Schour, I. 1944; Atlas of the Mouth and Adjacent Parts in Health and Disease. Chicago: American Dental Association.

Mays, S. 1993; Infanticide in Roman Britain. Antiquity 67: 883-8.

Mays, S. 2000; The archaeology and history of infanticide, and its occurrence in earlier British Populations. In J. Sofaer Derevenski, (Ed.) Children and Material Culture. London: Routledge:180-190.

Mays, S. and Eyers, J. 2011. Perinatal infant death at the Roman villa site at Hambleden, Buckinghamshire, England. Journal of Archaeological Science 38, 1931-38.

Mays, S. \& Faerman, M. 2001; Sex identification of some putative infanticide victims from Roman Britain using ancient DNA. Journal of Archaeological Science, Vol. 28: 555-559.

Meade, J. 2010; The Middle and Upper Ouse Valley in the Late Iron Age and Romano-British Periods: Divergent Identities? BAR British Series 512. Oxford: Archaeopress. 
Miller, Z. E. S. 2012; The Infant Burials from Piddington: A Case Study of Differential Infant Burial. In R. M. Friendship-Taylor \& D. E. Friendship-Taylor (Eds.), Iron Age and Roman Piddington: Human Burials of the Late Iron Age/Early Roman Infants, Cremations \& Anglo-Saxon burials from the Piddington Romano-British villa. The Upper Nene Archaeological Society 2012, Fascicule 12: 37-68.

Millet, M \& Gowland, R. 2015; Infant and Child Burial Rites in Roman Britain: A Study from East Yorkshire. Britannia, Vol. 46: 171-189.

Molleson, T. I. 1999; Archaeological evidence for attitudes to disability in the past. Archaeological Review from Cambridge 15: 69-72.

Moore, A. 2009. Hearth and home: the burial of infants within Romano-British domestic contexts. Childhood in the Past, Vol. 2: 33-54.

Moorrees, C. F. A. Fanning, E. A. \& Hunt, E. E. 1963a; Formation and Resorption of Three Deciduous Teeth in Children. American Journal of Physical Anthropology, Vol. 21: 205-213.

Moorrees C F A, E A Fanning, E E Hunt 1963b. Age Variation of Formation Stages for Ten Permanent Teeth. Journal of Dental Research, Vol. 42: 1490-502.

National Health Service Still Birth Statistics

(http://www.nhs.uk/conditions/Miscarriage/Pages/Introduction.aspx $)$

Non, A. L. Hollister, B. M. Humphreys, K. L. Childebayeva, A. Esteves, K. Zeanah, C. H. Fox, N. A. Nelson, C. A. and Drury, S. S. 2016; DNA Methylation at Stress-Related Genes is Associated with Exposure to Early Life Institutionalization. American Journal of Physical Anthropology, Vol. 161: 84-93.

Ortner, D. J. 2003; Identification of Pathological Conditions in Human Skeleton Remains. San Diego: Elsevier.

Ortner, D. J. \& Ericksen, M. F. 1997; Bone Changes in the Human Skull Probably Resulting from Scurvy in Infancy and Childhood. International Journal of Osteoarchaeology, Vol. 7: 212-220. 
Ortner, D. J. Kimmerle, E. H. \& Dies, M 1999; Probable Evidence of Scurvy in Subadults from Archaeological Sites in Peru. American Journal of Physical Anthropology, Vol. 108: 321-331.

Pearce, J. 1999; The dispersed dead: preliminary observations on burial and settlement space in rural Roman Britain. In Baker, P., Forcey, C., Jundi, S. and Witcher, R. (Eds.) TRAC 98: Proceedings of the 8th Annual Theoretical Roman Archaeology Conference: Leicester 1998. Oxford: Oxbow Books: $151-162$.

Pearce, J. 2001; Infants, cemeteries and communities in the Roman provinces. In D. Davis, A. Gardner and K. Lockyear (Eds.) TRAC 2000. Oxford: Oxbow: 125-142.

Rawson, B. 1986; Children in the Roman Familia. In B. Rawson (Ed.) The Family in Ancient Rome: New Perspectives. New York: Cornell University Press: 170-200.

Rawson, B. 2003; Children and Childhood in Roman Italy. Oxford: Oxford University Press.

Redfern, R. C. 2007; The influence of culture upon childhood: an osteological study of Iron Age and Romano-British Dorset. In M. Harlow and R. Laurence (Eds.) Age and Ageing in the Roman Empire. Portsmouth: Journal or Roman Archaeology: 171-194.

Redfern, R. C. and DeWitte, S. N. 2011; A New Approach to the Study of Romanization in Britain: A Regional Perspective of Cultural Change in Late Iron Age and Roman Dorset Using the Siler and Gompertz-Makeham Models of Mortality. American Journal of Physical Anthropology, Vol. 144: 269285.

Redfern, R. C. and Gowland, R. L. 2012; A bioarchaeological perspective on the pre-adult stages of the life course: implications for the care and health of children in the Roman Empire. In M. Harlow and L. Larsson Loven (Eds.) Families in the Roman and Late Antique World. London: Continuum: 111-140.

Redfern, R. C. Millard, A. R. and Hamlin, C. 2012; A regional investigation of subadult dietary patterns and health in late Iron Age and Roman Dorset, England. Journal of Archaeological Science, Vol. 39: 1249-1259.

Roberts, C. \& Manchester, K. 2010; The Archaeology of Disease. Stroud: The History Press. 
Ruff, C. B. Garofalo, E. and Holmes, M. A. 2013: Interpreting Skeletal Growth in the Past From a Functional and Physiological Perspective. American Journal of Physical Anthropology, Vol 150: 29-37.

Sandman, C. A. Glynn, L. M. and Poggi Davis, E. 2016; Neurobehavioral Consequences of Fetal Exposure to Gestational Stress. In N. Reissland \& B. S. Kisilevsky (Eds.) Fetal Development: Research on Brain and Behavior, Environmental Influences, and Emerging Technologies. Switzerland: Springer International Publishing: 229-265.

Schaefer, M. Black, S. \& Scheuer, L. 2009; Juvenile Osteology: A Laboratory and Field Manual. London: Elsevier Inc.

Scheuer, L. \& Black, S. 2000; Developmental Juvenile Osteology. Oxford: Elsevier Academic Press.

Scheuer, L. Musgrave, J. H. \& Evans, S. P. 1980; The estimation of late fetal and perinatal age from limb bone length by linear and logarithmic regression. Annals of Human Biology, 7 (3): 257-265.

Schour, I. and Massler, M. 1941; The development of the human dentition. Journal of the American Dental Association, Vol. 28: 1153-60.

Scott, E. 1991; Animal and infant burials in Romano-British villas: revitalization movement. In Garwood, P., Jennings, D., Skeates, R. and Toms, J. (Eds.) Sacred and Profane: Proceedings of a Conference on Archaeology, Ritual and Religion, Oxford 1989 (Oxford University Committee for Archaeology Monograph No. 32). Oxford: Oxbow Books: 115-121.

Scott, E. 1999; The Archaeology of Infancy and Infant Death. BAR International Series 819. Oxford: Archaeopress.

Shrader, R. E. \& Zemen, F. J. 1973; Skeletal Development in Rats as Affected by Maternal Protein Deprivation and Postnatal Food Supply. The Journal of Nutrition, Vol. 103: 792-801.

Smith, B.H. 1991; Standards of human tooth formation and dental age assessment. In M. A. Kelley and C. S. Larsen (Eds.) Advances in Dental Anthropology. New York: Wiley-Liss: 143-168. 
Smith, S. L. and Buschang, P. H. 2004; Variation in Longitudinal Diaphyseal Long Bone Growth in Children Three to Ten Years of Age. American Journal of Human Biology, Vol. 16: 648-657.

Tanner, J. M. 1978; Foetus Into Man: Physical Growth from Conception to Maturity. London: Open Books Publishing Ltd.

Thorsell, A. and Nätt, D. 2016; Maternal stress and diet may influence affective behavior and stressresponse in offspring via epigenetic regulation of central peptidergic function. Environmental Epigenetics, Vol. 2, No. 3: 1-10.

Ubelaker, D. H. 1978; Human Skeletal Remains: Excavation, Analysis, interpretation. Chicago: Aldine.

Upper Nene Archaeological Society 2009 Interim Report

(http://www.unas.org.uk/magazine/magview.php?ID=8\&date=0910\&secshun=2)

Webster, J. 2005. Archaeologies of slavery and servitude: bringing 'New World' perspectives to Roman Britain. Journal of Roman Archaeology 18:161-179.

White, T. D. \& Folkens, P. A. 2005; The Human Bone Manual. Elsevier Ltd: London.

Wiedemnn, T. 1989; Adults and Children in the Roman Empire. Abingdon Oxfordshire: Routledge.

Wu, G. Imhoff-Kunsch, B. and Webb Girard, A. 2012; Biological Mechanisms for Nutritional Regulation of Maternal Health and Fetal Development. Paediatric and Perinatal Epidemiology, Vol 26, Suppl.1: 426. 